\title{
Fixed point theorems for nonself Kannan type contractions in Banach spaces endowed with a graph
}

\section{LASZLO BALOG ${ }^{1}$ and VASILE BERINDE ${ }^{1,2}$}

\begin{abstract}
.
Let $K$ be a non-empty closed subset of a Banach space $X$ endowed with a graph $G$. The main result of this paper is a fixed point theorem for nonself Kannan $G$-contractions $T: K \rightarrow X$ that satisfy Rothe's boundary condition, i.e., $T$ maps $\partial K$ (the boundary of $K$ ) into $K$. Our new results are extensions of recent fixed point theorems for self mappings on metric spaces endowed with a partial order and also of various fixed point theorems for self and nonself mappings on Banach spaces or convex metric spaces.
\end{abstract}

Acknowledgements. The second author's research was done during his visit to Department of Mathematics and Statistics, King Fahd University of Petroleum and Minerals, Dhahran, Saudi Arabia, in the period April-May 2016. He gratefully thanks Dr. AlHomidan, dean of College of Sciences, and Dr. Al-Attas, the Chairman of the Department of Mathematics and Statistics, for the excellent conditions they offered during the visit.

The second author would like to acknowledge the support provided by the Deanship of Scientific Research at King Fahd University of Petroleum and Minerals for funding this work through the projects IN151014 and IN151017. The research was also supported by the CNCS-UEFISCDI project number PN-II-ID-PCE-2011-3-0087, ctr. No. 315.

\section{REFERENCES}

[1] Abbas, M., Ali, B. and Petruşel, G., Fixed points of set-valued contractions in partial metric spaces endowed with a graph, Carpathian J. Math., 30 (2014), No. 2, 129-137

[2] Agarwal, R. P., El-Gebeily, M. A. and O'Regan, D., Generalized contractions in partially ordered metric spaces, Appl. Anal., 87 (2008), 1-8

[3] Alghamdi, Maryam A., Berinde, V. and Shahzad, N., Fixed points of multi-valued non-self almost contractions, J. Appl. Math., Volume 2013, Article ID 621614, 6 pp.

[4] Alghamdi, Maryam A., Berinde, V. and Shahzad, N., Fixed points of non-self almost contractions, Carpathian J. Math., 33 (2014), No. 1, 1-8

[5] Ariza-Ruiz, D. and Jiménez-Melado, A., A continuation method for weakly Kannan maps, Fixed Point Theory Appl., 2010, Art. ID 321594, 12 pp.

[6] Assad, N. A. On a fixed point theorem of Iséki, Tamkang J. Math., 7 (1976), No. 1, 19-22

[7] Assad, N. A. On a fixed point theorem of Kannan in Banach spaces, Tamkang J. Math., 7 (1976), No. 1, 91-94

[8] Assad, N. A., On some nonself nonlinear contractions, Math. Japon., 33 (1988), No. 1, 17-26

[9] Assad, N. A., On some nonself mappings in Banach spaces, Math. Japon., 33 (1988), No. 4, 501-515

[10] Assad, N. A., Approximation for fixed points of multivalued contractive mappings, Math. Nachr., 139 (1988), 207-213

Received: 21.05.2016; In revised form: 22.06.2016; Accepted: 01.07.2016

2010 Mathematics Subject Classification. 47H10, 47H08, 47H09.

Key words and phrases. Banach space, graph, non self mapping, Kannan contraction, fixed point, property $(M)$, Rothe's boundary condition.

Corresponding author: Vasile Berinde; vasile.berinde@gmail.com 
[11] Assad, N. A., A fixed point theorem in Banach space, Publ. Inst. Math. (Beograd) (N.S.), 47 (1990), No. 61, $137-140$

[12] Assad, N. A., A fixed point theorem for some non-self-mappings, Tamkang J. Math., 21 (1990), No. 4, 387-393

[13] Assad, N. A. and Kirk, W. A., Fixed point theorems for set-valued mappings of contractive type, Pacific J. Math., 43 (1972), 553-562

[14] Assad, N. A. and Sessa, S., Common fixed points for nonself compatible maps on compacta, Southeast Asian Bull. Math., 16 (1992), No. 2, 91-95

[15] Berinde, V., A common fixed point theorem for nonself mappings, Miskolc Math. Notes, 5 (2004), No. 2, 137-144

[16] Berinde, V., Approximation of fixed points of some nonself generalized $\phi$-contractions, Math. Balkanica (N.S.), 18 (2004), No. 1-2, 85-93

[17] Berinde, V., Iterative Approximation of Fixed Points, 2nd Ed., Springer Verlag, Berlin Heidelberg New York, 2007

[18] Berinde, V. and Păcurar, M., Fixed point theorems for nonself single-valued almost contractions, Fixed Point Theory, 14 (2013), No. 2, 301-312

[19] Berinde, V. and Păcurar, M., The contraction principle for nonself mappings on Banach spaces endowed with a graph, J. Nonlinear Convex Anal., 16 (2015), No. 9, 1925-1936

[20] Berinde, V. and Păcurar, M., A constructive approach to coupled fixed point theorems in metric spaces, Carpathian J. Math., 31 (2015), No. 3, 277-287

[21] Berinde, V. and Petric, M. A., Fixed point theorems for cyclic non-self single-valued almost contractions, Carpathian J. Math., 31 (2015), No. 3, 289-296

[22] Bojor F., Fixed point of $\varphi$-contraction in metric spaces endowed with a graph, Ann. Univ. Craiova, Math. Comput., Sci. Ser., 37 (2010), No. 4, 85-92

[23] Bojor, F., Fixed points of Bianchini mappings in metric spaces endowed with a graph, Carpathian J. Math., 28 (2012), No. 2, 207-214

[24] Bojor, F., Fixed points of Kannan mappings in metric spaces endowed with a graph, An. Stiint. Univ. "Ovidius" Constanta Ser. Mat., 20 (2012), No. 1, 31-40

[25] Bojor, F., Fixed point theorems for Reich type contractions on metric spaces with a graph, Nonlinear Anal., 75 (2012), No. 9, 3895-3901

[26] Bojor, F., Fixed point theorems in in metric spaces endowed with a graph (in Romanian), PhD Thesis, North University of Baia Mare, 2012

[27] Caristi, J., Fixed point theorems for mappings satisfying inwardness conditions, Trans. Amer. Math. Soc., 215 (1976), 241-251

[28] Caristi, J., Fixed point theory and inwardness conditions, Applied nonlinear analysis (Proc. Third Internat. Conf., Univ. Texas, Arlington, Tex., 1978), pp. 479-483, Academic Press, New York-London, 1979

[29] Chatterjea, S. K., Fixed-point theorems, C. R. Acad. Bulgare Sci., 25 (1972) 727-730

[30] Chifu, C. and Petrussel, G., Generalized contractions in metric spaces endowed with a graph, Fixed Point Theory Appl., 2012, 2012:161, 9 pp.

[31] Cho, S.-H., A fixed point theorem for a Ćirić-Berinde type mapping in orbitally complete metric spaces, Carpathian J. Math., 30 (2014), No. 1, 63-70

[32] Choudhury, B. S, Das, K. and Bhandari, S. K., Cyclic contraction of Kannan type mappings in generalized Menger space using a control function, Azerb. J. Math., 2 (2012), No. 2, 43-55

[33] Ćirić, Lj. B., A remark on Rhoades' fixed point theorem for non-self mappings, Internat. J. Math. Math. Sci., 16 (1993), No. 2, 397-400

[34] Ćirić, Lj. B., Quasi contraction non-self mappings on Banach spaces, Bull. Cl. Sci. Math. Nat. Sci. Math., (1998), No. 23, 25-31

[35] Ćirić, Lj. B., Ume, J. S., Khan, M. S. and Pathak, H. K., On some nonself mappings, Math. Nachr., 251 (2003), 28-33

[36] Eisenfeld, J. and Lakshmikantham, V., Fixed point theorems on closed sets through abstract cones, Appl. Math. Comput., 3 (1977), No. 2, 155-167

[37] Filip, A.-D., Fixed point theorems for multivalued contractions in Kasahara spaces, Carpathian J. Math., 31 (2015), No. 2, 189-196

[38] Gabeleh, M., Existence and uniqueness results for best proximity points, Miskolc Math. Notes, 16 (2015), No. 1, 123-131

[39] Hussain, N., Salimi, P. and Vetro, P., Fixed points for $\alpha-\psi$-Suzuki contractions with applications to integral equations, Carpathian J. Math., 30 (2014), No. 2, 197-207

[40] Jachymski, J., The contraction principle for mappings on a metric space with a graph, Proc. Amer. Math. Soc., 136 (2008), No. 4, 1359-1373 
[41] Kannan, R., Some results on fixed points, Bull. Calcutta Math. Soc., 10 (1968), 71-76

[42] Kikkawa, M. and Suzuki, T., Some similarity between contractions and Kannan mappings. II, Bull. Kyushu Inst. Technol. Pure Appl. Math., (2008), No. 55, 1-13

[43] Kikkawa, M. and Suzuki, T., Some similarity between contractions and Kannan mappings, Fixed Point Theory Appl., 2008, Art. ID 649749, 8 pp.

[44] Kirk, W. A., Srinivasan, P. S. and Veeramani P., Fixed points for mappings satis- fying cyclical contractive conditions, Fixed Point Theory, 4 (2003), No. 1, 79-89

[45] Meszaros, J., A comparison of various definitions of contractive type mappings, Bull. Calcutta Math. Soc., 84 (1992), No. 2, 167-194

[46] Nicolae, A., O'Regan, D. and Petruşel, A., Fixed point theorems for singlevalued and multivalued generalized contractions in metric spaces endowed with a graph, Georgian Math. J., 18 (2011), No. 2, 307-327

[47] Nieto, J. J. and Rodriguez-Lopez, R., Contractive mapping theorems in partially ordered sets and applications to ordinary differential equations, Order 22 (2005), No. 3, 223-239 (2006)

[48] Nieto, J. J. and Rodriguez-Lopez, R., Existence and uniqueness of fixed point in partially ordered sets and applications to ordinary differential equations, Acta. Math. Sin., (Engl. Ser.) 23 (2007), No. 12, 2205-2212

[49] Nieto, Juan J., Pouso, Rodrigo L. and Rodriguez-Lopez, R., Fixed point theorems in ordered abstract spaces, Proc. Amer. Math. Soc., 135 (2007), No. 8, 2505-2517

[50] Panja, C. and Samanta, S. K., On determination of a common fixed point, Indian J. Pure Appl. Math., 11 (1980), No. 1, 120-127

[51] Păcurar, M., Approximating common fixed points of Prešić-Kannan type operators by a multi-step iterative method, An. Ştiinţ,. Univ. "Ovidius" Constanţa Ser. Mat., 17 (2009), No. 1, 153-168

[52] Păcurar, M., Iterative Methods for Fixed Point Approximation, Risoprint, Cluj-Napoca, 2010

[53] Păcurar, M., A multi-step iterative method for approximating fixed points of Prešić-Kannan operators, Acta Math. Univ. Comen. New Ser., 79 (2010), No. 1, 77-88

[54] Păcurar, M., A multi-step iterative method for approximating common fixed points of Prešić-Rus type operators on metric spaces, Stud. Univ. Babeş-Bolyai Math., 55 (2010), No. 1, 149-162

[55] Păcurar, M., Fixed points of almost Prešić operators by a k-step iterative method, An. Ştiint,. Univ. Al. I. Cuza Iaşi, Ser. Noua, Mat., 57 (2011), Supliment 199-210

[56] Petric, M., Some results concerning cyclical contractive mappings, Gen. Math., 18 (2010), No. 4, 213-226

[57] Petric, M., Best proximity point theorems for weak cyclic Kannan contractions, Filomat, 25 (2011), No. 1, 145-154

[58] Petruşel, A. and Rus, I. A., Fixed point theorems in ordered L-spaces, Proc. Amer. Math. Soc., 134 (2006), No. 2, $411-418$

[59] Ran, A. C. M. and Reurings, M. C. B., A fixed point theorem in partially ordered sets and some applications to matrix equations, Proc. Amer. Math. Soc., 132 (2004), No. 5, 1435-1443

[60] Rhoades, B. E., A comparison of various definitions of contractive mappings, Trans. Amer. Math. Soc., 226 (1977) $257-290$

[61] Rhoades, B. E., A fixed point theorem for some non-self-mappings, Math. Japon., 23 (1978/79), No. 4, 457-459

[62] Rhoades, B. E., Contractive definitions revisited, Contemporary Mathematics, 21 (1983), 189-205

[63] Rhoades, B. E., Contractive definitions and continuity, Contemporary Mathematics, 72 (1988), 233-245

[64] Rus, I. A., Principles and Applications of the Fixed Point Theory (in Romanian), Editura Dacia, Cluj-Napoca, 1979

[65] Rus, I. A., Generalized contractions, Seminar on Fixed Point Theory, 3 (1983), 1-130

[66] Rus, I. A., Generalized Contractions and Applications, Cluj University Press, Cluj-Napoca, 2001

[67] Rus, I. A., Picard operators and applications, Sci. Math. Jpn., 58 (2003), No. 1, 191-219

[68] Rus, I. A., Private communication (2015)

[69] Rus, I. A., Petruşel, A. and Petruşel, G., Fixed Point Theory, Cluj University Press, Cluj-Napoca, 2008

[70] Samanta, S. K., Fixed point theorems for non-self-mappings, Indian J. Pure Appl. Math., 15 (1984), No. 3, $221-232$

[71] Samanta, S. K., Fixed point theorems for Kannan maps in a metric space with some convexity structure, Bull. Calcutta Math. Soc., 80 (1988), No. 1, 58-64

[72] Samanta, C. and Samanta, S. K., Fixed point theorems for multivalued non-self mappings, Zb. Rad. Prirod.-Mat. Fak. Ser. Mat., 22 (1992), No. 1, 11-22

[73] Shukla, S. and Abbas, M., Fixed point results of cyclic contractions in product spaces, Carpathian J. Math., 31 (2015), No. 1, 119-126

[74] Sun, Y. I., Su, Y. F. and Zhang, J. L., A new method for the research of best proximity point theorems of nonlinear mappings, Fixed Point Theory Appl., 2014, 2014:116, 18 pp.

[75] Ume, J. S., Fixed point theorems for Kannan-type maps, Fixed Point Theory Appl., 2015, 2015:38, 13 pp. 
[76] Zhang, J. L. and Su, Y. F., Best proximity point theorems for weakly contractive mapping and weakly Kannan mapping in partial metric spaces, Fixed Point Theory Appl., 2014, 2014:50, 8 pp.

${ }^{1}$ Department of Mathematics and Computer Science

NORTH UNIVERSiTy CENTER AT BAIA MARE

TECHNICAL UNIVERSITY OF CLUJ-NAPOCA

VICTORIEI 76, 430122 BAIA MARE, ROMANIA

E-mail address: vberinde@ubm.ro

E-mail address: balog_58@yahoo.com

${ }^{2}$ Department of Mathematics and Statistics

King Fahd University of Petroleum and Minerals Dhahran, Saudi Arabia

E-mail address: vasile.berinde@gmail.com 